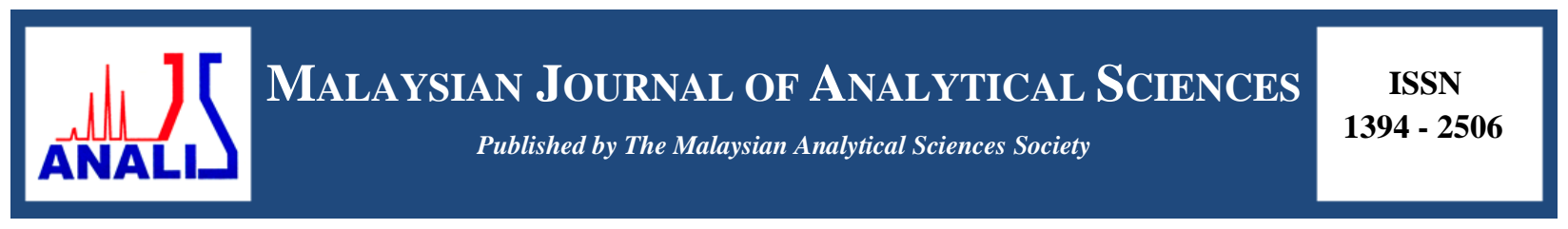

\title{
PREPARATION, CHARACTERIZATION AND PERFORMANCE OF POLYVINYLIDENE FLUORIDE/TETRAOCTYL PHOSPHONIUM BROMIDE NANOCOMPOSITE ULTRAFILTRATION MEMBRANE
}

\author{
(Penyediaan, Pencirian dan Prestasi Membran Ultraturasan Nanokomposit Polivinilidena \\ Flourida/Tetraoktil Fosfonium Bromida)
}

\author{
Asmadi Ali ${ }^{1}$, Connie Ling Mee $\mathrm{Yu}^{1}$, Nur Alyaa Mohd Sani ${ }^{1}$, Mohd Aidil Adha Abdullah ${ }^{2}$, Mohamad Awang ${ }^{1}$, \\ Nor Shalihan Mohamed ${ }^{1}$, Mohd Azizi Che Yunus ${ }^{3}$ \\ ${ }^{1}$ School of Ocean Engineering \\ ${ }^{2}$ School of Fundamental Science \\ Universiti Malaysia Terengganu, 21030 Kuala Nerus, Terengganu, Malaysia. \\ ${ }^{3}$ Centre of Lipid Engineering and Applied Research (CLEAR), \\ Ibnu Sina Institute for Industrial and Scientific Research, \\ Universiti Teknologi Malaysia, 81310 UTM Johor Bahru, Johor, Malaysia \\ *Corresponding author: asmadi@umt.edu.my
}

Received: 16 April 2017; Accepted: 7 March 2018

\begin{abstract}
Ultrafiltration (UF) membrane is widely used in many industrial areas and applications. Polyvinylidene fluoride (PVDF) is one of the commonly used materials for UF membrane fabrication due to its excellent properties. However, its hydrophobic nature causes the decrease of its demands and limits its applications. Hence, tetraoctyl phosphonium bromide (TOPBr) clay was used as a nanofiller material and was added into the PVDF matrix to decrease the hydrophobic surface through the antifouling properties of the PVDF/TOPBr nanocomposite membrane. The phase inversion process was employed for membrane fabrication which characterizes the water content and porosity of the PVDF/TOPBr nanocomposite UF membrane and to determine the performance of membrane in terms of pure water permeation, protein separation and fouling parameters. The results showed the increment of TOPBr dosage increases the water content and porosity, as well as enhances the porosity structure of PVDF/TOPBr nanocomposite membrane compared to the original PVDF membrane. The protein separation performance test revealed that after the addition of TOPBr, the flux increased from $2.06 \mathrm{~L} / \mathrm{m}^{2} . \mathrm{h}$ to $20.22 \mathrm{~L} / \mathrm{m}^{2} . \mathrm{h}$ with a $1.0 \mathrm{wt} . \%$ increase in protein separation as a result of the increase in the membrane hydrophilicity and porosity of the nanocomposite membrane. Moreover, PVDF/TOPBr1.0 nanocomposite showed the highest antifouling properties and flux recovery at 93\% compared to other $\mathrm{PVDF} / \mathrm{TOPBr}$, as well as the native PVDF membrane.
\end{abstract}

Keywords: ultrafiltration, nanocomposite membrane, polyvinylidene fluoride, clay

\begin{abstract}
Abstrak
Membran ultraturasan (UF) digunakan secara meluas dalam banyak industri dan aplikasinya. Polivinilidena fluorida (PVDF) adalah bahan yang biasanya digunakan untuk fabrikasi membran kerana mempunyai sifat yang cemerlang. Walaubagaimanapun, sifat asal yang hidrofobik menyebabkan penurunan permintaannya dan menghadkan penggunaannya. Maka, tanah liat tetraoktil fosfonium bromida (TOBr) telah digunakan sebagai bahan pengisi nano dan ditambah ke dalam matrik PVDF untuk mengurangkan permukaan hidrofobik melalui sifat antikotoran oleh membran nanokomposit PVDF/TOPBr. Proses fasa sonsangan digunakan untuk fabrikasi membran yang mencirikan kandungan air dan keliangan membran nanoomposit $\mathrm{PVDF} / \mathrm{TOPBr}$ dan untuk menentukan prestasi membran dari segi penyerapan air tulen, pemisahan protein dan parameter pengotoran. Keputusan menunjukkan kenaikan dos $\mathrm{TOPBr}$ meningkatkan kandungan air dan keliangan, serta meningkatkan
\end{abstract}




\section{Asmadi et al: PREPARATION, CHARACTERIZATION AND PERFORMANCE OF POLYVINYLIDENE FLUORIDE/TETRAOCTYL PHOSPHONIUM BROMIDE NANOCOMPOSITE ULTRAFILTRATION MEMBRANE}

struktur keliangan membran nanokomposit PVDF/TOPBr berbanding dengan membran PVDF asal. Ujian prestasi pemisahan protein menunjukkan bahawa selepas penambahan TOPBr, fluks meningkat dari $2.06 \mathrm{~L} / \mathrm{m}^{2} . \mathrm{h}$ kepada $20.22 \mathrm{~L} / \mathrm{m}^{2} . \mathrm{h} \mathrm{dengan}$ kenaikan 1.0 wt.\% dalam pemisahan protein akibat daripada peningkatan hidrofilik membran dan keliangan membran nanokomposit. Selain itu, nanokomposit PVDF/TOPBr1.0 menunjukkan sifat antikotoran yang tertinggi dan pemulihan fluks pada 93\% berbanding dengan PVDF /TOPBr yang lain serta membran PVDF asli.

Kata kunci: ultraturasan, membran nanokomposit, polivinilidena fluorida, tanah liat

\section{Introduction}

Membrane technology has provided a good opportunity and presents an interesting approach to study separation processes in numerous applications, such as in water and wastewater treatment, gas purification, food processing, pharmaceutical industries and bio separation areas [1]. In recent years, the application of UF membrane in protein separation is growing rapidly as it is easy to operate, incurs a low operating cost and does not involve any phase change. In this light, producing membranes with better separation characteristics is important to the continued development of this technology. Most of the membranes used commercially based on polymeric materials and made from hydrophobic polymers such as polysulfone (PS), polyether sulfone (PES), polypropylene (PP), polyethylene (PE), and polyvinylidene fluoride (PVDF). Among of these various polymers, PVDF is a well-known polymeric membrane that has broadly been used in UF membrane separation process.

PVDF has been used in various applications, particularly in ultrafiltration processes due to its excellent chemical resistance, thermal stability and mechanical properties. However, PVDF membrane has a highly hydrophobic nature which leads to the deposition of solute or particle on a membrane surface or in membrane pores, causing serious fouling and a rapid decline in permeation flux [2]. The hydrophobicity of PVDF membrane has limited the application of the commercial PVDF membrane. Thus, it is necessary to improve the hydrophilicity of PVDF membrane through chemical or physical modifications,surface grafting polymerization, coating, or blending with a hydrophilic polymer [3]. Among these methods, blending with inorganic materials, especially nanoparticles has attracted much interest due to its simple operation and efficiency in enhancing the performance of the hydrophobic membranes in designing new materials [4]. In this regard, montmorillonite is one of the most familiar natural clay used in the preparation of polymer clay nanocomposite membrane because of its ability to be dispersed in the polymeric matrices at nanoscopic level [5] and only a small amount of this material is needed in the fabrication of nanocomposite membrane [6]. Thus, this study investigated the preparation of PVDF/Montmorillonite nanocomposite membrane using organically modified clay, tetraoctyl phosphonium bromide (TOPBr) by using the blending method.

To the best of our knowledge, there is no research conducted that focused on the use of clay materials in the nanocomposite membrane. The purpose of this research is to prepare flat sheet PVDF/TOPBr nanocomposite UF membranes by phase inversion method and to characterize its characteristics and performance by investigating the effect of clay dosage on water permeation and protein separation in detail.

\section{Materials}

\section{Materials and Methods}

All materials used were of analytical grade. The membranes were fabricated from the dope solution of polyvinylidene fluoride (PVDF) as the base polymer, tetraoctyl phosphonium bromide (TOPBr) clay, and Nmethyl-2-pyrrolidone (NMP) as a solvent. All of these materials were supplied by Merck. The TOPBr clay was prepared via cation ion exchange between sodium ions of $\mathrm{Na}^{+} \mathrm{MMT}$ clay and tetraoctylphosphonium bromide (TOP-Br) surfactant ions. The modified clay was prepared according to Ali and his co-workers [3]. Distilled water was used as a coagulation medium in coagulation bath and was used in pure water permeation experiment. Bovine serum albumin $(\mathrm{BSA})(\mathrm{Mw}=66 \mathrm{kDa})$ purchased from Sigma was used for the evaluation of the protein separation performance test.

\section{Membrane preparation}

The membranes were prepared using the phase inversion method. Different TOPBr clay content $(0.2,0.4,0.6,0.8$ and 1.0 weight $\%$ ) were added into $17 / 83 \mathrm{wt} . \%$ of polymer/solvent solution and homogenous dispersion solutions 
were prepared by mechanical stirring for 6 hours at $70{ }^{\circ} \mathrm{C}$. The membranes were fabricated via phase inversion technique where the solution was cast on a glass plate with $150-\mu \mathrm{m}$ thickness and immediately immersed into a coagulation bath. A flat sheet membrane was obtained and stored for 24 hours, in order to remove the excess solvent in the fabricated membrane. The membranes were stored in distilled water prior to usage.

\section{Membrane characterization: Water content}

The water content of each membrane was obtained after soaking the membranes in water for 24 hours at room temperature. The membranes were then dried in a vacuum drier at $75{ }^{\circ} \mathrm{C}$ for 48 hours befire the weight of each membrane was determined. The percentage of water content was calculated using equation 1 :

$$
\% \text { Water content }=\frac{\left(W_{\text {wet }}-W_{d r y}\right)}{W_{\text {wet }}} \times 100
$$

where $W_{\text {wet }}$ is define as weight of is wet membrane $(\mathrm{mg})$ and $W_{d r y}$ is a weight of dry membrane (mg).

\section{Porosity}

The porosity of each membrane was assessed by their holding ability for water absorption and was determined using the equation 2 below:

$$
\text { Porosity }=\frac{\left(W_{1}-W_{2} / d_{\text {water }}\right)}{V} \times 100
$$

where $W_{1}$ and $W_{2}$ are the mass of membrane in wet and dry states $(\mathrm{mg}), d_{\text {water }}$ is the density of water at room temperature $(\mathrm{ml} / \mathrm{mg})$ and $V$ is the volume of the membrane in wet state $(\mathrm{ml})$.

\section{Pure water permeation}

All of the permeation tests were carried out at room temperature using dead end permeation cell with the feed volume of $300 \mathrm{ml}$ and area of membrane filtration was set at $14.6 \mathrm{~cm}^{2}$. Distilled water was used for the feed solution in this experiment to earn pure water permeability and achieve membrane stability. Compaction tests were performed for each membrane, first at 5 bar between 30 minutes to 1 hour or until the pure water flux attained a steady state. After the compaction process, the distilled water was drawn through the membrane using compressed nitrogen gas with the operating pressure ranging from 1 to 5 bar. The equation 3 below was used to calculate pure water flux:

$$
P W P\left(L / m^{2} \cdot h\right)=\frac{Q}{A \Delta T}
$$

where $Q$ is a permeate collection quantity (L), $A$ is area of the membrane $\left(\mathrm{m}^{2}\right)$ and $\Delta T$ time of sampling (hour).

\section{Separation performance}

For the BSA permeation, $0.1 \mathrm{mg} / \mathrm{ml}$ BSA solution were prepared in phosphate buffer at room temperature. The permeate solutions of the corresponding membranes were evaluated by using UV-Vis spectrophotometer at wavelength $280 \mathrm{~nm}$. The value obtained from the absorbance of feed and concentration of permeate can be used to calculate the rejection percentage using the equation 4 below:

$$
R(\%)=\left(1-\frac{C_{p}}{C_{f}}\right) \times 100
$$

where $C_{p}$ and $C_{f}$ were concentrations of protein in the permeate and in the feed, respectively.

\section{Fouling analysis test}

Fouling can be measured by the resistance that occurred during the process of filtration and cleaning can be determined by the elimination of resistance. Pure water permeation was operated in pressure constant of 3 bars. The volume of permeated water was collected within 30 minutes and assumed as a pure water flux $\left(\mathrm{J}_{0}\right)$. It can be 


\section{Asmadi et al: PREPARATION, CHARACTERIZATION AND PERFORMANCE OF POLYVINYLIDENE FLUORIDE/TETRAOCTYL PHOSPHONIUM BROMIDE NANOCOMPOSITE ULTRAFILTRATION MEMBRANE}

calculated using equation (3). After measuring the water flux $\left(\mathrm{J}_{0}\right)$, the cell was unloaded and refilled with BSA solution. After 3 hour filtration, the permeate flux of BSA solution $\left(\mathrm{J}_{\mathrm{BSA}}\right)$ was recorded and the membranes were cleaned by shaking in pure water for 30 minutes. The pure water flux $\left(\mathrm{J}_{1}\right)$ after cleaning was measured in a similar way as $\mathbf{J}_{0}$. By comparing the value of $\mathbf{J}_{0}$ and $\mathbf{J}_{1}$, flux recovery ratio (FRR) can be determined using equation 5 below:

$$
\operatorname{FRR}(\%)=\left(\frac{J_{1}}{J_{0}}\right) \times 100
$$

The reversible fouling ratio (RRF) and irreversible fouling ratio (RIRF) were obtained by using the following equations:

$$
\begin{aligned}
& R_{R F}(\%)=\left(\frac{J_{1}-J_{B S A}}{J_{0}}\right) \times 100 \\
& R_{I R F}(\%)=\left(\frac{J_{0}-J_{1}}{J_{0}}\right) \times 100
\end{aligned}
$$

where $J_{o}$ is define as the pure water flux before the BSA solution filtration, $J_{1}$ is the pure water flux after cleaning and $J_{B S A}$ is the BSA solution flux after 3 hour of protein filtration.

\section{Water content and porosity}

\section{Results and Discussion}

Water content and porosity are two membrane characteristics which are indirectly linked to the hydrophilicity properties of the membrane. These two important parameters are involved in the membrane permeation and separation process and are closely linked to membranes morphology. The results of water content and membrane porosity with different clay contents are shown in Figure 1.

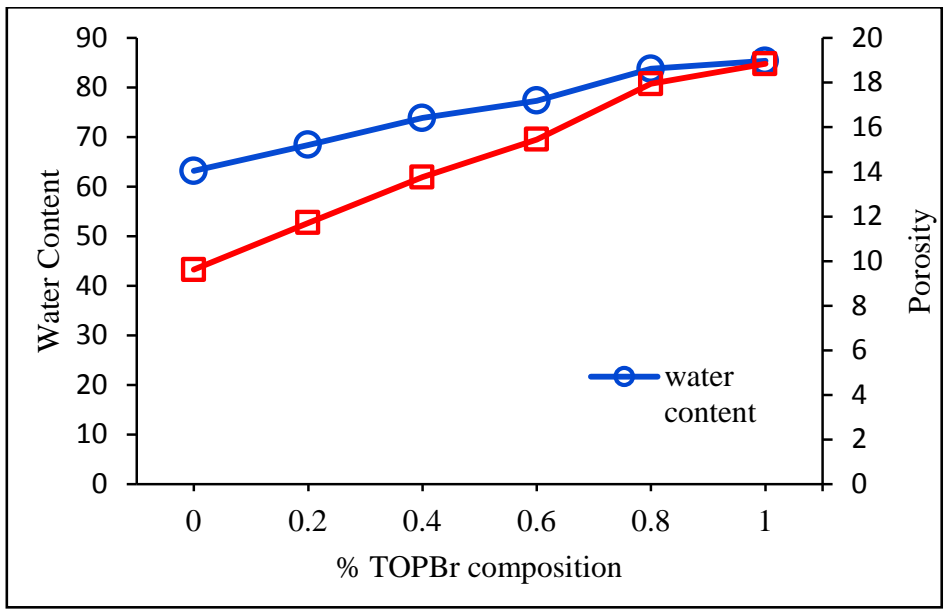

Figure 1. Water content and porosity of native PVDF membrane and PVDF/TOPBr nanocomposite membranes with different TOP-Br contents

It could be observed that the increase in water content is directly proportional to the increase in clay content. The water content of native membrane was $63 \%$ and increased to $68 \%$ after $0.2 \%$ of TOPBr clay were added. Meanwhile, for PVDF/TOPBr1.0, which contains 1wt.\% of TOPBr clay, further addition of TOPBr clay in the $\mathrm{PVDF} / \mathrm{TOPBr}$ nanocomposite membrane further increased the water content up to $85 \%$. The increase in water content is due to the increment in void volume resulting in the formation of bigger pore size structure that consequently, increases the water uptake in the pores $[7,8]$. 
A similar trend was observed on the porosity of PVDF/TOP-Br membranes. The increase in the clay content has increased the porosity of membranes where the hydrophilicity of the TOP-Br clay causes the increase in the exchanges of solvent and non-solvent that occur during the phase inversion process. This leads to the higher porosity in the membrane cross sectional area and the increase in the water uptake in the pores [7,9]. Due to the low PVDF concentration of $17 \mathrm{wt} . \%$, the compositions of the nanoclays were varied from $0.2-1.0 \mathrm{wt} . \%$ to overcome high dope viscosity and avoid the aggregation of nanoclays on the membrane surface. According to Ahmad et al. [10], the most suitable addition of nanoparticles into low polymer concentration in the range $15-17 \mathrm{wt} . \%$ is lower than 2.0 wt. \% which consequently produces a product with low aggregation tendencies without blocking the membrane pores. This promises excellent final membrane hydrophilicity properties in terms of water content, porosity, permeability, as well as antifouling properties compared to the pure membranes.

\section{Pure water permeation}

In order to obtain the membrane permeability coefficient and membrane stability, all fabricated membranes were subjected to the pure water permeation process. The graph of pure water flux versus pressure is shown in Figure 2 . All of the samples were measured at five different pressures ranging from 1 to $5 \mathrm{bar}$. It was observed that the pure water flux of all membranes increased linearly with the increase in the operating pressure. The native membrane recorded the lowest value of pure water flux which might be due to the hydrophobicity of the polymer itself. An increase of $0.2 \%$ to $1.0 \%$ of TOPBr clay content has made the PVDF membranes to become more hydrophilic. PVDF/TOPBr1.0 showed the highest pure water flux compared to the other PVDF/TOPBr nanocomposite membranes. The increase of membrane porosity and hydrophilicity with the increase in the content of TOPBr clay can attract more water molecules inside the membrane matrix and promote the water molecules to pass through the membrane and enhance their permeability. This is due to the exchange process between the non-solvent in coagulation bath and solvent in the polymer dope that enhances the pore size of the membrane and increases the filtration area $[9,11,12]$.

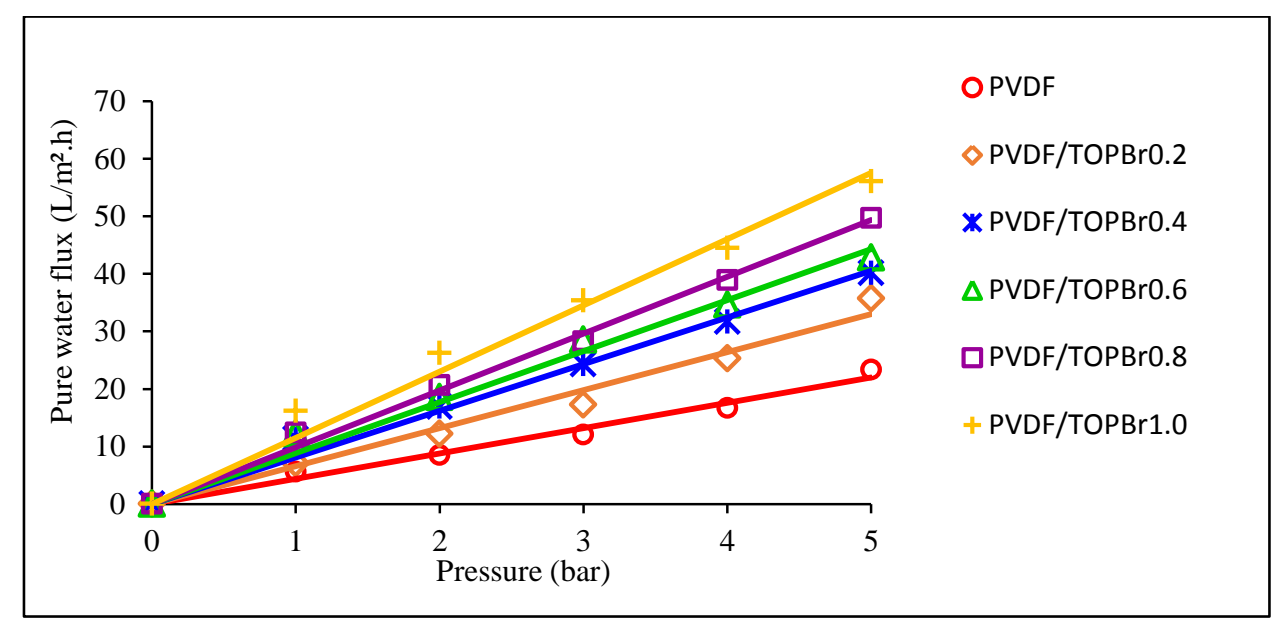

Figure 2. Pure water permeation (PWP) for native PVDF membrane and PVDF/TOPBr nanocomposite membranes with different TOP-Br contents

Table 1 shows the permeability and regression coefficient of native PVDF and PVDF/TOPBr nanocomposite membranes. Permeability coefficient also represents the porosity and as an indicator of its hydraulic resistance of UF membranes. The native PVDF membrane showed the lowest permeability coefficient while PVDF/TOPBr1.0 showed the highest permeability coefficient. This means that the lower permeability coefficient, the higher the membrane hydraulic resistance which represent membranes that are as less porous and dense. Table 1 clearly depicts that as the TOPBr clay content increases, the permeability coefficient also increase. 


\section{Asmadi et al: PREPARATION, CHARACTERIZATION AND PERFORMANCE OF POLYVINYLIDENE FLUORIDE/TETRAOCTYL PHOSPHONIUM BROMIDE NANOCOMPOSITE ULTRAFILTRATION MEMBRANE}

Table 1. Permeability coefficient and regression coefficient for native PVDF membrane and PVDF/TOPBr nanocomposite membrane with different clay composition

\begin{tabular}{lcc}
\hline Membrane & $\begin{array}{c}\text { Permeability Coefficient } \\
\left(\mathbf{L} / \mathbf{m}^{2} \mathbf{. h . b a r}\right)\end{array}$ & $\begin{array}{c}\text { Regression Coefficient } \\
\left(\mathbf{R}^{\mathbf{2}}\right)\end{array}$ \\
\hline Native & 4.3996 & 0.9835 \\
PVDF/TOPBr0.2 & 6.5985 & 0.9801 \\
PVDF/TOPBr0.4 & 8.0997 & 0.9889 \\
PVDF/TOPBr0.6 & 8.8646 & 0.9919 \\
PVDF/TOPBr0.8 & 9.8673 & 0.9942 \\
PVDF/TOPBr1.0 & 11.5060 & 0.9816 \\
\hline
\end{tabular}

\section{Protein separation performance}

The prepared membranes were further evaluated by applying the separation of BSA solution. Figure 3 displays the graph of the permeate flux and solute rejection through $\mathrm{PVDF} / \mathrm{TOPBr}$ nanocomposite membranes of different dosages of clay at the pressure level of 3 bar. It can be observed that the permeate flux has increased while the BSA rejection showed a fluctuated trend with the increase of the clay dosage. Only a slight increase of rejection was observed for the dosages of TOPBr clay ranging from $0.6 \%$ until $1.0 \%$. The increase in the rejection values is due to the negative charges which are inherent in the silicate structure due to the homogeneity between the TOPBr clay in the polymer solution. Ali et al. [13] explained that the pore size on the membrane surface becomes smaller due to the close segmental gap between polymer chains for blend polymer membrane and consequently increased the protein rejection. A further increase of flux from $2.06 \mathrm{~L} / \mathrm{m}^{2}$.h to $20.22 \mathrm{~L} / \mathrm{m}^{2} . \mathrm{h}$ was observed when the dosage of $\mathrm{TOPBr}$ is at $1.0 \%$. This may be due to the increase in porosity and the hydrophilicy of the membrane. In this light, membrane performance depends on the porosity, thickness, as well as the hydophilicy of the membrane. These properties improve the membrane resistance to fouling and allow better stability of the permeate flux [14].

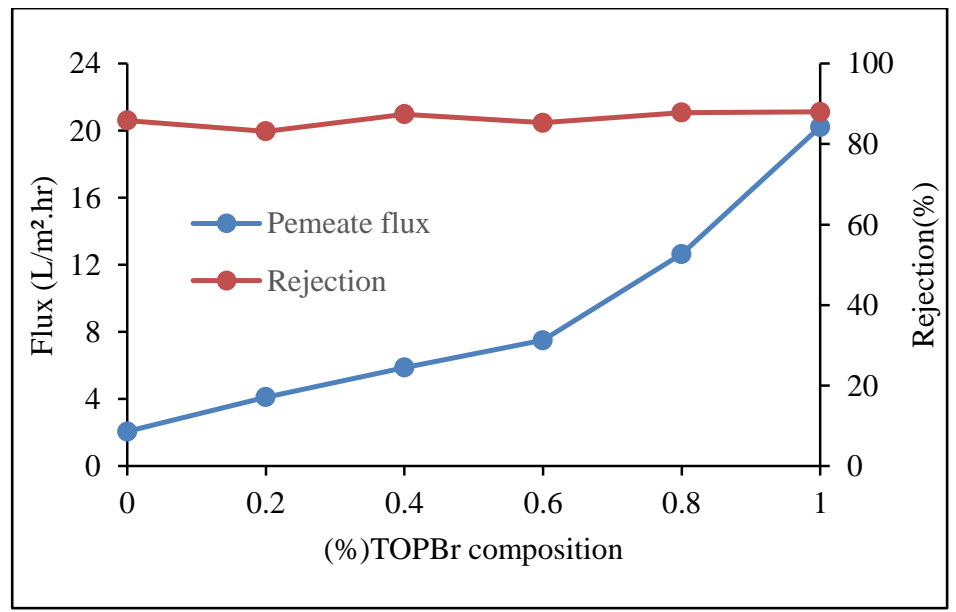

Figure 3. Permeate flux and solute rejection for native membrane and PVDF/TOPBr nanocomposite membrane with different dosage of clay

\section{Fouling Analysis Test}

The results of fouling analysis tests are shown in Figure 4. Theoretically, a better antifouling property in the membrane is related to the higher fouling ratio. Membrane fouling is associated with the adsorption of BSA protein on the surface of the membranes or inside the membrane pores which consist of reversible and irreversible fouling. Reversible fouling occurs from the building up of protein solutes on the membrane surface which can be easily 
removed by simple hydraulic cleaning while irreversible fouling is caused by the strong deposition of protein molecules attached to the surface and the entrapment of protein molecules into the pores. These protein molecules remained and only a few would be removed even after the membranes were cleaned [15]. It can be observed that PVDF/TOPBr1.0 nanocomposite membrane shows the highest flux recovery ratio (FRR) value with 93\% followed by PVDF/TOPBr0.8 with $88 \%$. This result might be linked to the high porosity of both membranes which prevent the extensive accumulation of BSA on the membrane surface and membrane pores. A flux reduction will still appear due to the slightly irreversible fouling ratio (RIFR).

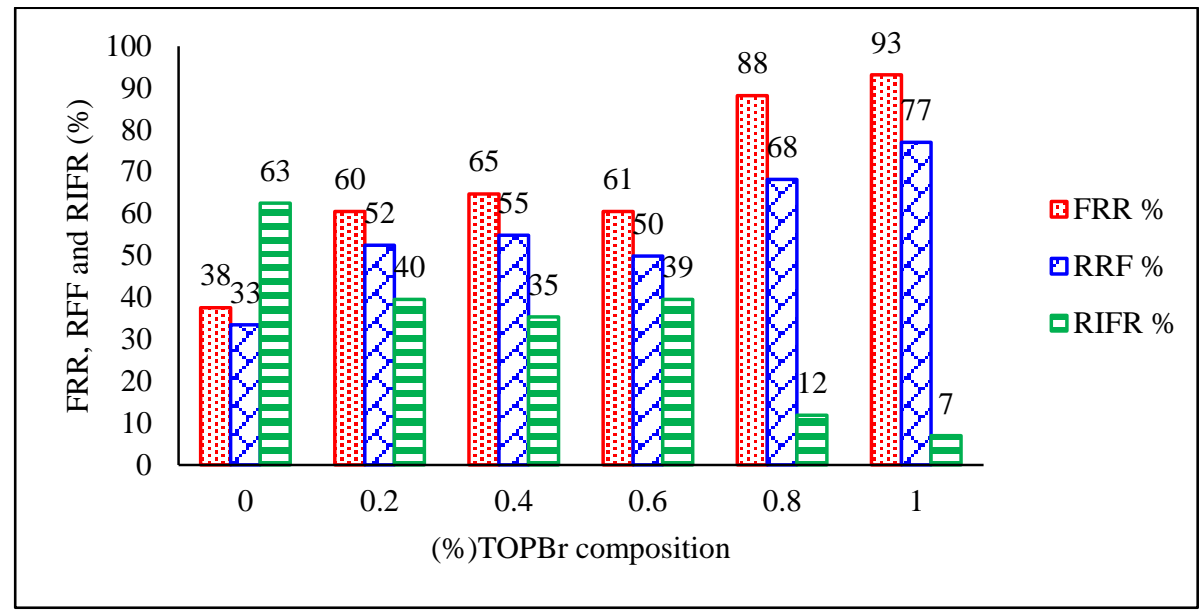

Figure 4. Flux recovery ratio (FRR), reversible fouling ratio (RRF) and irreversible fouling ratio (RIFR) of membranes

It was observed that native PVDF has the lowest value of flux recovery ratio with just $38 \%$ and a reduction of flux occurred when the irreversible fouling ratio is at highest value (63\%). The fast blocking of membrane pores was caused by the low membrane porosity that occurred during the initial filtration stage since the cleaning membrane cleaning did not improve the membrane flux. The growth of cake layer on the membrane surface will form and reduce the flux permeation and consequently, decrease the value of FRR. This can be considered as the impact of membrane fouling which leads to an increase in hydraulic resistance and reduction of filtration efficiency [16-18].

\section{Conclusion}

This study has investigated the effect of the presence of TOPBr clay at different weight compositions on the properties of $\mathrm{PVDF} / \mathrm{TOPBr}$ nanocomposite membrane focusing on its characteristics, pure water permeation, protein separation tests and fouling parameters. The results showed that varying the $\mathrm{TOPBr}$ clay composition in the PVDF polymer will produce membranes with different characteristics and performance. In this light, the presence of higher composition $\mathrm{TOPBr}$ clay in the nanocomposite membrane increased water content and porosity of PVDF/TOPBr nanocomposite membrane. The protein separation performance test revealed that after the addition of TOPBr, the flux increased from $2.06 \mathrm{~L} / \mathrm{m}^{2} . \mathrm{h}$ to $20.22 \mathrm{~L} / \mathrm{m}^{2}$.h with a $1.0 \mathrm{wt} . \%$ increase in protein separation as a result of the increase in the membrane hydrophilicity and porosity of the nanocomposite membrane. Moreover, PVDF/TOPBr1.0 nanocomposite showed the highest antifouling properties and flux recovery at $93 \%$ compared to other PVDF/TOPBr, as well as the native PVDF membrane. The addition of TOPBr clay showed a positive effect on membrane flux and hydrophilicity and has improved the membrane's surface resistance against protein fouling. Lastly, flux recovery and antifouling of all $\mathrm{PVDF} / \mathrm{TOPBr}$ nanocomposite membranes have improved after $\mathrm{TOPBr}$ clay was blended into the membrane matrix.

\section{Acknowledgement}

The authors are grateful for research financial support by the Ministry of Higher Education, Malaysia under Fundamental Research Grant Scheme (FRGS) (Grant no.59351). 


\section{References}

1. Kang, G. and Cao, Y. (2014). Application and modification of polyvinylidene flouride (PVDF) membranes - A review. Journal of Membrane Science, 463: 145-165.

2. Rajabi, H., Ghaemi, N., Madaeni, S. S., Daraei, P., Ali, M. and Falsafi, M. (2014). Nanoclay embedded mixed matrix PVDF nanocomposite membrane: preparation, characterization and biofouling resistance. Applied Surface Science, 313: 207-214.

3. Ismail, N. M., Ismail, A. F. and Mustaffa, A. (2014). Characterization of polyethersulfone/cloisite 15A mixed matrix membrane for $\mathrm{CO}_{2} / \mathrm{CH}_{4}$ separation. Jurnal Teknologi, 9: 83-87.

4. Wu, G., Gan, S., Cui, L. and $\mathrm{Xu}$, Y. (2008). Preparation and characterization of $\mathrm{PES} / \mathrm{TiO}_{2}$ composite membranes. Applied Surface Science, 254(21): 7080-7086.

5. Zulhairun, A. K., Ismail, A. F., Matsuura, T., Abdullah, M. S. and Mustafa, A. (2014). Asymmetric mixed matrix membrane incorporating organically modified clay particle for gas separation. Chemical Engineering Journal, 241: 495-503.

6. Ali, A., Mohamed, N. S., Awang, M. and Mohd Sani, N. A. (2016). Preparation and characterization of alkylphosphonium modified montmorillonite. International Journal of Applied Chemistry, 12(1): 93-98.

7. Ali, A., Yunus, R. M., Awang, M., Johari, A. and Mat, R. (2014). Effect of cellulose acetate phthalate (CAP) on characterics and morphology of polysulfone/cellulose acetate phthalate (Psf/CAP) blend membranes. Applied Mechanics and Materials, 493: 640-644.

8. Ameduri, B. (2009). From vinylidene fluoride (PVDF) to the applications of VDF-containing polymers and copolymers: recent developments and future trends. Chemical Reviews, 109(12): 6632-6686.

9. Ali, A., Awang, M., Mat, R., Johari, A., Kamaruddin, M. J. and Sulaiman, W. R. W. (2014). Influence of hydrophilic polymer on pure water flux, permeability coefficient, and porosity of polysulfone blend membranes. Advanced Materials Research, 931-932: 168-172.

10. Ahmad, A. L., Abdulkarim, A. A., Ooi, B. S. and Ismail, S. (2013). Recent development in additives modifications of polyethersulfone membrane for flux enhancement. Chemical Engineering Journal, 223: 246267.

11. Arthanareeswaran, A., Devi, T. K. S. and Raaajenthiren, M. (2008). Effect of silica particles on cellulose acetate blend ultrafiltration membranes: Part 1. Separation and Purification Technology, 64 (1): 38-47.

12. Arthanareeswaran, A. and Thanikaivelan, P. (2010). Fabrication of cellulose acetate-zirconia hybrid membranes for ultrafiltration applications: Performance, structure and fouling analysis. Separation and Purification Technology, 74(2): 230-235.

13. Ali, A., Yunus, M. R., Awang, M. and Yunus, C. M. A. (2015). Influence of hydrophilic polymer on proteins separation, molecular weight cut-off (MWCO) and average pore size of polysulfone blend Membrane. Jurnal Teknologi, 74(7): 53-56.

14. Anadão, P., Sato, L. F., Montes, R. R. and Santis, H. S. De. (2014). Polysulphone/montmorillonite nanocomposite membranes: Effect of clay addition and polysulphone molecular weight on the membrane properties. Journal of Membrane Science, 455: 187-199.

15. Monticelli, O., Bottino, A., Scandale, I., Capannelli, G. and Russo, S. (2006). Preparation and properties of polysulfone - clay composite membranes. Journal of Applied Science, 103(6): 3637-3644.

16. Daraei, P., Madaeni, S. S., Ghaemi, N., Khadivi, M. A., Astinchap, B. and Moradian, R. (2013). Enhancing antifouling capability of PES membrane via mixing with various type of polymer modified multi-walled carbon nanotube. Journal of Membrane Science, 444: 184-191.

17. Zularisam, A. W., Ismail, A. F., Salim, M. R., Sakinah, M. and Ozaki, H. (2007) The effects of natural organic matter (NOM) fractions on fouling characteristics and flux recovery of ultrafiltration membranes. Desalination: 212(1-3): 191-208.

18. Zulkali, M. M. D., Ahmad, A. L. and Derek, C. J. C. (2005). Membrane application in proteomic studies: preliminary studies on the effect of $\mathrm{pH}$, ionic strength and pressure on protein fractionation. Desalination: 179(1-3): 381-390. 